\title{
Aluminum overload increases oxidative stress in four functional brain areas of neonatal rats
}

\author{
Chia-Yi Yuan ${ }^{1}$, Yih-Jing Lee ${ }^{2^{*}}$ and Guoo-Shyng Wang Hsu ${ }^{3^{*}}$
}

\begin{abstract}
Background: Higher aluminum (Al) content in infant formula and its effects on neonatal brain development are a cause for concern. This study aimed to evaluate the distribution and concentration of $\mathrm{Al}$ in neonatal rat brain following Al treatment, and oxidative stress in brain tissues induced by Al overload.

Methods: Postnatal day 3 (PND 3) rat pups $(n=46)$ received intraperitoneal injection of aluminum chloride $\left(\mathrm{AlCl}_{3}\right)$, at dosages of 0,7 , and $35 \mathrm{mg} / \mathrm{kg}$ body wt (control, low $\mathrm{Al}(\mathrm{LA})$, and high $\mathrm{Al}(\mathrm{HA})$, respectively), over $14 \mathrm{~d}$.

Results: Aluminum concentrations were significantly higher in the hippocampus $(751.0 \pm 225.8 \mathrm{ng} / \mathrm{g}$ v.s. $294.9 \pm$ $180.8 \mathrm{ng} / \mathrm{g} ; p<0.05)$, diencephalon (79.6 $20.7 \mathrm{ng} / \mathrm{g}$ v.s. $20.4 \pm 9.6 \mathrm{ng} / \mathrm{g} ; p<0.05)$, and cerebellum (144.8 \pm 36.2 $\mathrm{ng} / \mathrm{g}$ v.s. $83.1 \pm 15.2 \mathrm{ng} / \mathrm{g} ; p<0.05)$ in the HA group compared to the control. The hippocampus, diencephalon, cerebellum, and brain stem of HA animals displayed significantly higher levels of lipid peroxidative products (TBARS) than the same regions in the controls. However, the average superoxide dismutase (SOD) activities in the cerebral cortex, hippocampus, cerebellum, and brain stem were lower in the HA group compared to the control. The HA animals demonstrated increased catalase activity in the diencephalon, and increased glutathione peroxidase (GPx) activity in the cerebral cortex, hippocampus, cerebellum, and brain stem, compared to controls.
\end{abstract}

Conclusion: Aluminum overload increases oxidative stress $\left(\mathrm{H}_{2} \mathrm{O}_{2}\right)$ in the hippocampus, diencephalon, cerebellum, and brain stem in neonatal rats.

Keywords: Aluminum, Neonatal rats, Functional brain tissues, Intraperitoneal injection

\section{Background}

Increasing evidence has demonstrated that oxidative stress is the primary cause of pathogenesis in inflammatory, partial ischemia, metabolic, and denatured cranial nerve disease [1]. Brain tissues are highly susceptible to oxidative damage, probably because of high oxygen consumption rate $(20 \%)$, the presence of abundant polyunsaturated fatty acids in cell membranes, high iron $(\mathrm{Fe})$ content, and low anti-oxidative enzyme activities [2]. Although aluminum (Al) is a relatively low redox mineral, it can induce oxidative damage through multiple mechanisms. It can bind to negatively charged brain phospholipids, which contain polyunsaturated fatty acids and are easily attacked by reactive oxygen species (ROS) such as $\mathrm{O}_{2}^{-}, \mathrm{H}_{2} \mathrm{O}_{2}, \mathrm{OH}^{-}$, and

\footnotetext{
* Correspondence: yjlee@mail.fju.edu.tw; 002613@mail.fju.edu.tw

${ }^{2}$ School of Medicine, Fu-Jen Catholic University, 510 Chung-Cheng Road, Hsinchuang, New Taipei City 24205, Taiwan

${ }^{3}$ Department of Nutritional Science, Fu-Jen Catholic University, 510 Chung-

Cheng Road, Hsinchuang, New Taipei City 24205, Taiwan

Full list of author information is available at the end of the article
}

$\mathrm{OH}^{-}$[3]. Aluminum can also stimulate iron-initiated lipid peroxidation in the Fenton reaction, which causes ROS production and $\mathrm{Fe}^{3+}$ formation. Superoxide $\left(\mathrm{O}_{2}^{-}\right)$is neutralized by $\mathrm{Al}^{3+}$ to form an $\mathrm{Al}-\mathrm{O}_{2}^{-}$complex, which increases the oxidative capacity of $\mathrm{O}_{2}^{-}$[4].

Reactive oxygen species may also cause cellular damage, by oxidizing amino acid residues on proteins, forming protein carbonyls [5]. The study of Kowalczyk et al. showed that three months' administration of aluminum chloride in drinking water at a dose of $80 \mathrm{mg} / \mathrm{l}$ significantly elevated protein carbonyl groups concentration in erythrocytes hemolysate [6]. Lesions existed in the brains of Alzheimer's disease $(\mathrm{AD})$ patients are typically associated with attacks by free radicals, and $\mathrm{Al}$ is shown to have catalytic activity to produce free radicals. In addition, beta-amyloid protein in the brain of $\mathrm{AD}$ patients is aggregated and induces more free radicals production [7].

Several studies have shown that oxidative stress induced by $\mathrm{Al}$ modifies the peroxidation of lipids and the activities of anti-oxidative enzymes. Julka and Gill

\section{Biomed Central}


(1996) [8] identified increased peroxidation of lipids in brain tissues of adult Wistar rats following administration of $10 \mathrm{mg} / \mathrm{d} \mathrm{Al}$ (aluminum lactate) for $4 \mathrm{wk}$. Oral administration of $\mathrm{Al}$ acetate $(4000 \mathrm{mg} \mathrm{Al} / \mathrm{kg}$ body wt and $6000 \mathrm{mg} \mathrm{Al} / \mathrm{kg}$ body wt) for $8 \mathrm{wk}$ resulted in higher lipid peroxidative products (thiobarbituric acid reactive substances, or TBARS) in mouse brain tissue lysates [9]. In the study of Katyal et al, aluminum treatment increased hyperoxidation of cerebral proteins [10]. A different study, however, observed that lower $\mathrm{Al}^{3+}(12.5$ $\mu \mathrm{mol} / \mathrm{L}$ ) inhibited oxidation of mouse cerebellar tissue proteins, while higher $\mathrm{Al}^{3+}(25 \mu \mathrm{mol} / \mathrm{L}$ and $50 \mu \mathrm{mol} / \mathrm{L})$ increased oxidation of the proteins [11]. Aluminum can, therefore, induce protective effects against oxidative stress and also cause damaging effects through oxidative stress.

The main route of $\mathrm{Al}$ excretion is the urine; therefore, subjects with kidney malfunction or immature kidney, such as nephropathy patients or neonates, might experience toxic accumulation of $\mathrm{Al}$ in the body [12]. Infant formula is the primary food source for bottle-fed neonates. The study of Yuan et al reviewed several other studies and reported that most commercial infant formulas contained higher $\mathrm{Al}(6.5 \mu \mathrm{M}$ to $87 \mu \mathrm{M})$ than human breast milk $(0.2 \mu \mathrm{M}$ to $1.7 \mu \mathrm{M})$ [12]. Infants display rapid growth and their brain-blood-barrier, detoxification system (liver), and excretory system (kidney) are not well-developed [13,14]. Aluminum can cross the blood-brain barrier and accumulate in glial and neural cells [15]. Thus, high intake of Al-containing formula might cause accumulation of $\mathrm{Al}$ in the neonatal brain, interfering with appropriate development.

In previous studies, exposure to excess dietary $\mathrm{Al}$ during gestation and lactation periods had no toxic effects on the mother, but resulted in persistent neurobehavioral deficits in the pups, such as defects in the sensory motor reflexes, locomotor activity, learning capability, and cognitive behavior $[16,17]$. These behavioral studies, therefore, suggested that $\mathrm{Al}$ exposure might cause developmental changes in neonatal brain. Until recently, a marker with which to effectively detect neonatal brain development was lacking. The group's previous study with $\mathrm{Al}$ treatment in neonatal rat hippocampal neurons at concentrations of $37 \mu \mathrm{M}$ and $74 \mu \mathrm{M}$ for 14 days significantly reduced NMDAR ( $\mathrm{N}$-methyl-D-aspartate receptor) expression which was used as a marker of brain development. This suggested that $\mathrm{Al}$ exposure might influence the development of hippocampal neurons in neonatal rats [12].

In previous studies on adult animals, $\mathrm{Al}$ induced the production of ROS and caused oxidative damage in the brain [3-11]. Neonatal animal studies also identified that Al exposure during gestation and lactation periods induced brain developmental deficits in pups $[12,16,17]$.
Thus, the hypothesis of the present study was that ROS might be the cause of developmental damage in the neonatal brain following $\mathrm{Al}$ administration. In order to effectively induce an $\mathrm{Al}$ overload state in animals, the experiments, therefore, involved intraperitoneal injection of equivalent amounts of $\mathrm{Al}\left(\mathrm{AlCl}_{3}\right)$ into PND 3 neonatal rats during a $14 \mathrm{~d}$ lactation period. The deposition of $\mathrm{Al}$, oxidative stress related enzyme activities as well as thiobarbituric acid reactive substances (TBARS) in functional areas of growing brain tissue were analyzed.

\section{Methods}

\section{Experimental design}

Postnatal day 3 (PND 3) SD rats were randomly divided into 3 experimental groups, which received intraperitoneal injection of different $\mathrm{AlCl}_{3}$ (Merck 801081) loads for $14 \mathrm{~d}$ : control (normal saline), low $\mathrm{Al}$ (LA, $7 \mathrm{mg} \mathrm{Al} /$ $\left.\mathrm{kg} / \mathrm{d}, 1 / 530 \mathrm{LD}_{50}\right)$, and high $\mathrm{Al}(\mathrm{HA}, 35 \mathrm{mg} \mathrm{Al} / \mathrm{kg} / \mathrm{d}, 1 /$ $\left.106 \mathrm{LD}_{50}\right)$. The $\mathrm{Al}$ content, levels of thiobarbituric acid reactive substances (TBARS), and activities of superoxide dismutase (SOD), catalase, and glutathione peroxidase (GPx) in the cerebral cortex, hippocampus, diencephalon, cerebellum, brain stem, pituitary, and olfactory bulb were evaluated.

\section{Animals and breeding}

Mature Sprague-Dawley (SD) rats were purchased from the Laboratory Animal Center of National Applied Research Laboratories Taiwan. The processes of protocols using experimental animals were approved by the Institutional Animal Care and Use Committee (IACUC) of Fu-Jen University. All rats were kept individually in stainless steel cages under a 12/12 h light-dark cycle, at $20^{\circ} \mathrm{C}$ to $22^{\circ} \mathrm{C}$ in a $60 \%$ humidity animal room. Standard laboratory chow (Purine Lab. Chow 5001, St. Louis, $\mathrm{MO}$ ) and DI water (Millipore, Milli-Q Ultra pure water system, $18.2 \Omega \mathrm{M} / \mathrm{cm}$ ) were provided ad lib. After $1 \mathrm{wk}$ adaptation, one male and one female rat were put into the same cage for mating. The pregnant female rats were kept individually in plastic cages for approximately $21 \mathrm{~d}$ gestation. Within $24 \mathrm{~h}$ of delivery, 10 newborn pups were placed in a cage with the maternal rat and breastfed. Forty-six neonatal pups were divided into the 3 experimental groups: control $(\mathrm{n}=16)$, LA $(\mathrm{n}=16)$, and HA $(n=14)$. Based on the study of Guo et al [18], dosages of 0 (control), 7 (LA), and 35 (HA) $\mathrm{mg} \mathrm{Al} / \mathrm{kg}$ body wt./d $\left(\mathrm{AlCl}_{3}\right)$ were intraperitoneally injected into each neonatal pup for $14 \mathrm{~d}$.

\section{Sample preparation}

Animals were anesthetized and decapitated on PND 17. The cerebral cortex, hippocampus, diencephalon, cerebellum, brain stem, pituitary, and olfactory bulb were collected. After weighing, a section of each tissue sample 
was frozen at $-70^{\circ} \mathrm{C}$ for $\mathrm{Al}$ content analysis; the other parts were homogenized on ice using various sample buffers. After centrifugation, supernatants were collected and frozen at $-70^{\circ} \mathrm{C}$ for oxidative product and antioxidative enzyme analyses.

\section{Determination of Al content}

After wet acid digestion of brain tissues, the $\mathrm{Al}$ contents in all samples were determined by using a flameless atomic absorption spectrophotometer (AAS, 903GBC, GBC, Australia) with a graphite furnace (System 3000, GBC, Australia). The instrument was adjusted at a wavelength of $309.3 \mathrm{~nm}$, with a slit of $0.5 \mathrm{~nm}$ and a Hollow cathode $\mathrm{Al}$ lamp (GBC). A lamp current of $8.0 \mathrm{~mA}$, integration time of $1 \mathrm{~s}$, double beam, and $\mathrm{D}_{2}$ background correction were used.

\section{Oxidative product and anti-oxidative enzyme assays}

The TBARS was measured as the parameter of the lipid peroxidation of samples according to the protocols described previously [19]. Lipid peroxides in the sample by repeat heating with acid would generate the second product which would react with thiobarbituric acid (TBA) to form TBARS with the maximal absorbance in $532 \mathrm{~nm}$.

The anti-oxidative enzyme SOD activity was evaluated using the Cayman Chemical Superoxide Dismutase Assay Kit (chemical Item Number 706002). $\mathrm{O}_{2}^{-}$and $\mathrm{H}^{+}$ produced by lipids in the sample react with hypoxanthine catalyzed by xanthine oxidase to generate the products, $\mathrm{H}_{2} \mathrm{O}_{2}$ and $\mathrm{O}_{2}$. The enzyme levels increase with decreasing of substrate, i.e. $\mathrm{O}_{2}^{-}[20]$.

The anti-oxidative enzyme catalase was evaluated using the Cayman Chemical Catalase Assay Kit (chemical Item Number 707002). Methanol reacts with $\mathrm{H}_{2} \mathrm{O}_{2}$ catalyzed by catalase to form formaldehyde. Formaldehyde and Purpald (4-amino-3-hydrazino- 5-mercapto-1,2,4triazole) produce a purple color in which the absorbance at $540 \mathrm{~nm}$ is positively correlated with the enzyme activity [21].

The anti-oxidative enzyme GPx was evaluated using the Cayman Chemical Glutathione Peroxidase Assay Kit (chemical Item Number 703102). Oxidized glutathione (GSSG), produced upon reduction of an organic hydroperoxide by GPx, is recycled to its reduced state by GR and NADPH. The oxidation of NADPH to NADP ${ }^{+}$is accompanied by a decrease in absorbance at $340 \mathrm{~nm}$. The rate of decrease in the A340 is directly proportional to the GPx activity in the sample [22].

\section{Determination of protein level}

The protein quantization of each brain tissue was determined by Pierce Coomassie ${ }^{\circledR}$ Plus Protein Assay Reagent Kit (chemical Item Number 23236). Basically when
Table 1 Final body weight, body weight gains, the brain tissues weights $(\mathbf{g})$ of neonatal pups after 2-weeks of intraperitoneal administration of $\mathrm{AlCl}_{3} 1,2,3$

\begin{tabular}{|c|c|c|c|}
\hline & Control $(n=16)$ & $\mathrm{LA}(\mathrm{n}=16)$ & $\mathrm{HA}(n=14)$ \\
\hline & (g) & (g) & (g) \\
\hline Final body weight & $29.9 \pm 3.1$ & $28.6 \pm 7.7$ & $30.2 \pm 5.1$ \\
\hline Body weight gains & $21.3 \pm 1.5$ & $17.9 \pm 9.0$ & $20.7 \pm 5.2$ \\
\hline Whole brain & $1.53 \pm 0.28$ & $1.29 \pm 0.10$ & $1.36 \pm 0.14$ \\
\hline Cerebral cortex & $0.44 \pm 0.12$ & $0.37 \pm 0.08$ & $0.40 \pm 0.09$ \\
\hline Hippocampus & $0.09 \pm 0.03$ & $0.09 \pm 0.01$ & $0.10 \pm 0.04$ \\
\hline Diencephalon & $0.44 \pm 0.09$ & $0.39 \pm 0.06$ & $0.40 \pm 0.06$ \\
\hline Cerebellum & $0.21 \pm 0.05^{a}$ & $0.14 \pm 0.03^{b}$ & $0.14 \pm 0.04^{b}$ \\
\hline Brain stem & $0.24 \pm 0.06^{a}$ & $0.21 \pm 0.03^{a b}$ & $0.19 \pm 0.05^{b}$ \\
\hline Pituitary gland & $0.05 \pm 0.01$ & $0.04 \pm 0.02$ & $0.05 \pm 0.02$ \\
\hline Olfactory bulb & $0.06 \pm 0.02^{a b}$ & $0.04 \pm 0.01^{b}$ & $0.08 \pm 0.04^{a}$ \\
\hline
\end{tabular}

${ }^{1}$ Values are mean \pm SD.

${ }^{2}$ Intraperitoneal (IP) administered $\mathrm{AlCl}_{3}$ of $0,7,35 \mathrm{mg} \mathrm{Al} / \mathrm{kg}$ body wt/day for 2 weeks in control, low $\mathrm{Al}(\mathrm{LA})$ and high $\mathrm{Al}(\mathrm{HA})$ groups respectively.

${ }^{3}$ Values in the same raw with different ${ }^{a}$, b superscripts are significantly different $(p<0.05)$.

Coomassie ${ }^{\circledR}$ Dye binds protein in an acidic medium, an immediate shift in absorption maximum occurs from $465 \mathrm{~nm}$ to $595 \mathrm{~nm}$ with a concomitant color change from brown to blue [23].

\section{Statistical analysis}

Data are expressed as mean \pm SD and were analyzed using Statistical Analysis System (SAS), version 9.2. One-way analysis of variance (ANOVA) was conducted to detect differences in the measurement values among groups, followed by Schaffer's test. Pearson's correlation analysis was used to assess the correlation among

Table 2 Relative brain tissue weight to body weight ratio in neonatal pups after 2-weeks intraperitoneal administration of $\mathrm{AlCl}_{3}$ 1,2,3,4

\begin{tabular}{|c|c|c|c|}
\hline & Control $(n=16)$ & $\mathrm{LA}(\mathrm{n}=16)$ & $\mathrm{HA}(n=14)$ \\
\hline & (\%) & (\%) & $\overline{(\%)}$ \\
\hline Whole brain & $5.24 \pm 1.51$ & $4.76 \pm 1.09$ & $4.66 \pm 1.12$ \\
\hline Cerebral cortex & $1.52 \pm 0.53$ & $1.36 \pm 0.42$ & $1.36 \pm 0.42$ \\
\hline Hippocampus & $0.30 \pm 0.13$ & $0.31 \pm 0.07$ & $0.35 \pm 0.19$ \\
\hline Diencephalon & $1.50 \pm 0.44$ & $1.47 \pm 0.45$ & $1.36 \pm 0.29$ \\
\hline Cerebellum & $0.71 \pm 0.24^{a}$ & $0.53 \pm 0.16^{a b}$ & $0.48 \pm 0.18^{b}$ \\
\hline Brain stem & $0.83 \pm 0.26$ & $0.78 \pm 0.21$ & $0.64 \pm 0.22$ \\
\hline Pituitary gland & $0.18 \pm 0.05$ & $0.16 \pm 0.06$ & $0.18 \pm 0.06$ \\
\hline Olfactory bulb & $0.21 \pm 0.09^{a b}$ & $0.16 \pm 0.05^{b}$ & $0.28 \pm 0.15^{a}$ \\
\hline \multicolumn{4}{|c|}{$\begin{array}{l}{ }^{1} \text { Values are mean } \pm \mathrm{SD} \text {. } \\
2 \text { Intraperitoneal (IP) administered } \mathrm{AlCl}_{3} \text { of } 0,7,35 \mathrm{mg} \mathrm{Al} / \mathrm{kg} \text { body wt/day for } 2 \\
\text { weeks in control, low } \mathrm{Al}(\mathrm{LA}) \text { and high } \mathrm{Al}(\mathrm{HA}) \text { groups respectively. } \\
{ }^{3} \text { Values in the same raw with different }{ }^{\text {a, b }} \text { superscripts are significantly } \\
\text { different ( } \mathrm{p}<0.05) \text {. }\end{array}$} \\
\hline
\end{tabular}


Table 3 Al contents in the brain tissues of neonatal pups after 2-weeks intraperitoneal administration of $\mathrm{AlCl}_{3}$ 1,2,3

\begin{tabular}{lccc}
\hline & Control $(\mathbf{n}=\mathbf{8})$ & LA $(\mathbf{n}=8)$ & HA $(\mathbf{n}=\mathbf{7})$ \\
\hline Whole brain $(\mathrm{ng} / \mathrm{g})$ & $165.5 \pm 37.9^{\mathrm{b}}$ & $167.4 \pm 32.8^{\mathrm{b}}$ & $219.5 \pm 43.1^{\mathrm{a}}$ \\
\hline Cerebral cortex $(\mathrm{ng} / \mathrm{g})$ & $60.9 \pm 7.5$ & $61.5 \pm 26.1$ & $60.4 \pm 11.4$ \\
\hline Hippocampus $(\mathrm{ng} / \mathrm{g})$ & $294.9 \pm 180.8^{\mathrm{b}}$ & $492.0 \pm 236.8^{\mathrm{ab}}$ & $751.0 \pm 225.8^{\mathrm{a}}$ \\
\hline Diencephalon $(\mathrm{ng} / \mathrm{g})$ & $20.4 \pm 9.6^{\mathrm{b}}$ & $46.9 \pm 33.9^{\mathrm{b}}$ & $79.6 \pm 20.7^{\mathrm{a}}$ \\
\hline Cerebellum $(\mathrm{ng} / \mathrm{g})$ & $83.1 \pm 15.2^{\mathrm{b}}$ & $88.1 \pm 21.6^{\mathrm{b}}$ & $144.8 \pm 36.2^{\mathrm{a}}$ \\
\hline Brain stem $(\mathrm{ng} / \mathrm{g})$ & $42.0 \pm 6.1$ & $41.0 \pm 13.0$ & $57.4 \pm 21.8$ \\
\hline Pituitary gland $(\mathrm{mg} / \mathrm{g})$ & $3.08 \pm 1.42$ & $2.34 \pm 0.49$ & $2.42 \pm 0.82$ \\
\hline Olfactory bulb (ng/g) & $173.9 \pm 42.2$ & $183.7 \pm 36.9$ & $171.2 \pm 75.3$ \\
\hline
\end{tabular}

${ }^{1}$ Values are mean \pm SD.

${ }^{2}$ Intraperitoneal (IP) administered $\mathrm{AlCl}_{3}$ of $0,7,35 \mathrm{mg} \mathrm{Al} / \mathrm{kg}$ body wt/day for 2 weeks in control, low $\mathrm{Al}(\mathrm{LA})$ and high $\mathrm{Al}(\mathrm{HA})$ groups respectively.

${ }^{3}$ Values in the same raw with different ${ }^{\mathrm{a}, \mathrm{b}}$ superscripts are significantly different $(p<0.05)$

variables. A $p$-value $<0.05$ was considered statistically significant.

\section{Results}

\section{Effects of Al on animal growth}

Results indicated no significant differences in the body weight gain among the 3 groups during the experimental period $(p>0.05)$. However, the cerebellar weights were significantly lower in the $\mathrm{Al}$ groups than in the control group (0.14 \pm 0.04 (HA), $0.14 \pm 0.03$ (LA), $0.21 \pm 0.05$ (control) g; $p<0.05$ ) (Table 1). Similarly, the brain stem weights were significantly lower in the HA group than in the control group $(0.19 \pm 0.05$ g v.s. $0.24 \pm 0.06$ g; $p$ $<0.05)$. The weights of the olfactory bulb were significantly higher in the HA group than in the LA group $(0.08 \pm 0.04$ g v.s. $0.04 \pm 0.01$ g; $p<0.05)$. The average cerebellar weight to body weight ratio was significantly lower in the HA group than in the control group $(0.48 \pm 0.18 \%$ v.s. $0.71 \pm 0.24 \% ; p<0.05)$, while the average olfactory bulb weight to body weight ratio was significantly higher in the HA group than in the LA group $(0.28 \pm 0.15 \%$ v.s. $0.16 \pm 0.05 \% ; p<0.05)$ (Table 2$)$.

\section{Aluminum content in different brain tissues}

After injection of $\mathrm{AlCl}_{3}$ for $2 \mathrm{wk}$, the hippocampus $(751.0 \pm 225.8$ v.s. $294.9 \pm 180.8 \mathrm{ng} / \mathrm{g} ; \quad p<0.05)$, diencephalon (79.6 \pm 20.7 v.s. $20.4 \pm 9.6 \mathrm{ng} / \mathrm{g} ; p<0.05)$, and cerebellum $(144.8 \pm 36.2$ v.s. $83.1 \pm 15.2 \mathrm{ng} / \mathrm{g} ; p$ $<0.05)$ of the HA group displayed significantly higher $\mathrm{Al}$ contents than those of the control group (Table 3). A similar trend was observed in the brain stem, although there were no significant differences between the Altreated and control groups $(57.4 \pm 21.8$ (HA), $41.0 \pm 13.0$ (LA), $42.0 \pm 6.1$ (control) ng/g; $p>0.05$ ). The $\mathrm{Al}$ groups displayed no accumulation of $\mathrm{Al}$ in the cerebral cortex, pituitary, and olfactory bulb when compared with the control group. Results indicated that the levels of $\mathrm{Al}$ in the diencephalon, hippocampus, cerebellum, and brain stem of the HA group were 4.0-, 2.5-, 1.7-, and 1.3-fold respectively, of that in the control group. Aluminum, thus, more easily aggregated in these 4 regions than in other tissues in the neonatal brain.

\section{Oxidative products in different brain tissues}

As shown in Figure 1, the hippocampus displayed higher levels of lipid peroxide products in the HA group than in the LA and control groups $(35.26 \pm 0.88$ (HA), $23.67 \pm 6.77$ (LA), $26.69 \pm 1.46$ (control) nmol/mL; $p$ $<0.05)$. The diencephalon displayed significantly higher levels of lipid peroxide products in both Al-treated groups than in the control group (30.08 \pm 6.71 , $29.64 \pm 4.26,17.55 \pm 6.31 \mathrm{nmol} / \mathrm{mL} ; p<0.05)$. Lipid peroxide product levels were significantly higher in the cerebellum in the HA group than in the LA and control groups (31.51 $\pm 3.48,21.32 \pm 2.23,21.19 \pm 1.33 \mathrm{nmol} / \mathrm{mL}$; $p<0.05)$. Similarly, the brain stem lipid peroxide product levels were significantly higher in the HA group than in the LA and control groups $(41.98 \pm 0.42,30.49 \pm 3.36$, $32.29 \pm 1.21 \mathrm{nmol} / \mathrm{mL} ; p<0.05)$. The levels of lipid peroxidative products (TBARS) in the hippocampus, diencephalon, cerebellum, and brain stem tissues were,

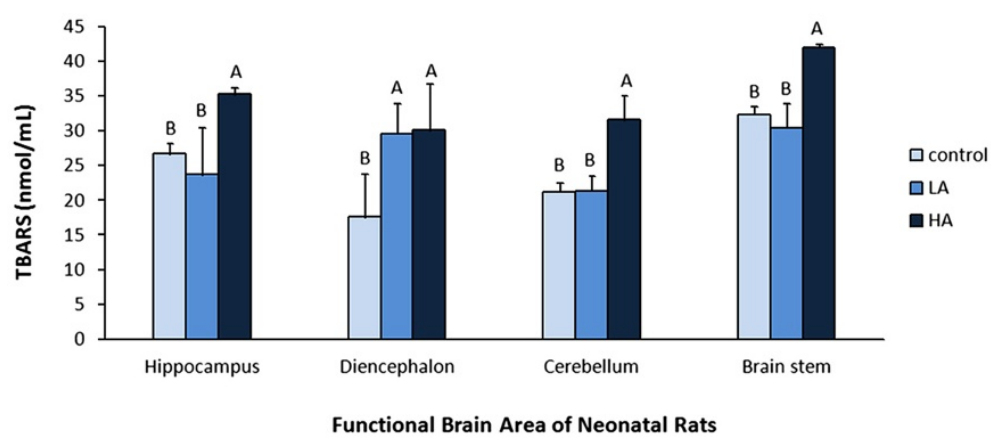

Figure 1 TBARS concentrations of brain tissues in neonatal pups after 2-weeks intraperitoneal administration of $\mathrm{AICl}_{3}$. Intraperitoneal (IP) administered $\mathrm{AlCl}_{3}$ of $0,7,35 \mathrm{mg} \mathrm{Al} / \mathrm{kg}$ body wt/day for 2 weeks in control, low $\mathrm{Al}(\mathrm{LA})$ and high $\mathrm{Al}$ (HA) groups respectively. Values in the figure with different ${ }^{A, B}$ superscripts are significantly different $(p<0.05)$. 

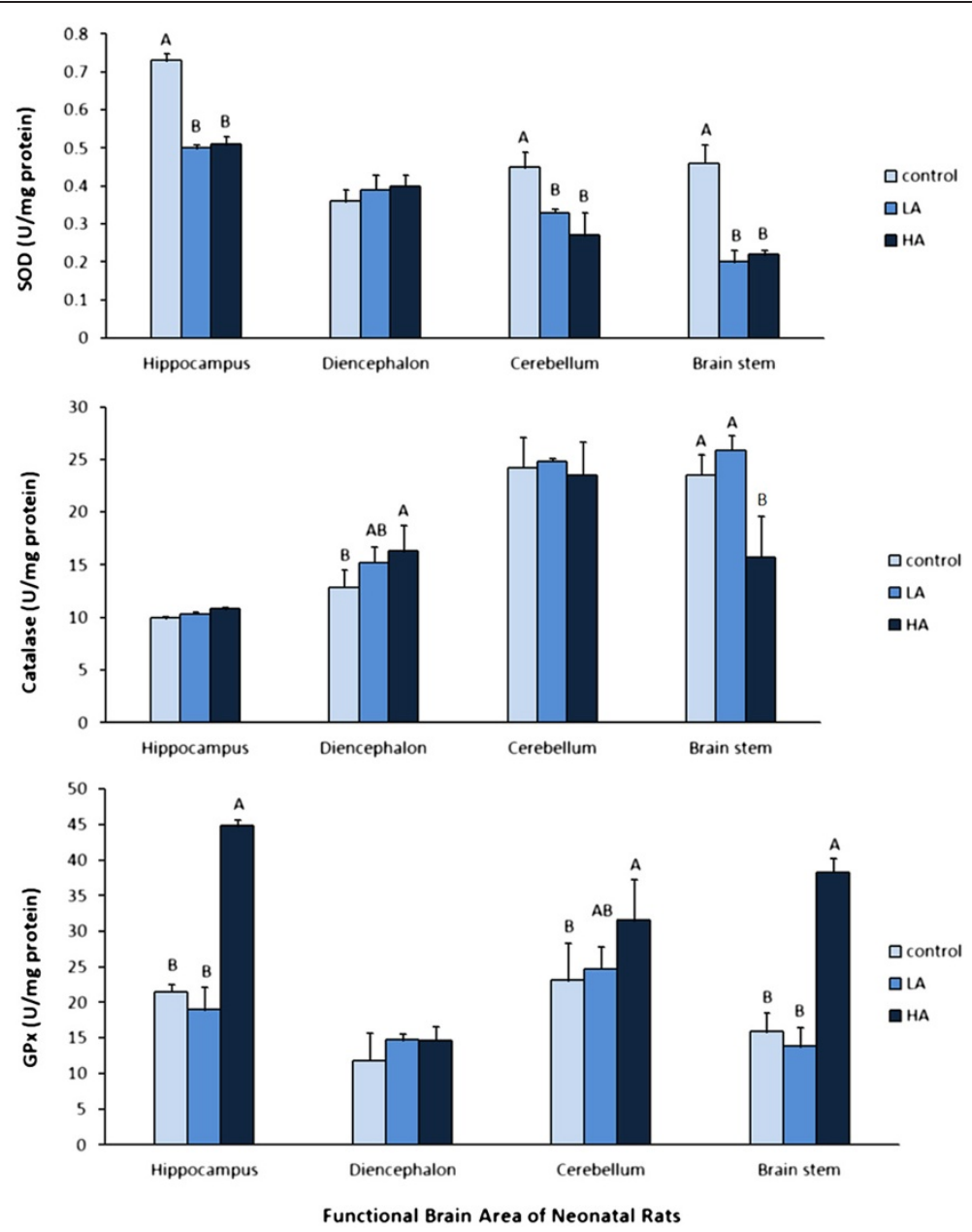

Figure 2 Specific activities of anti-oxidative enzymes of brain tissues in neonatal pups after 2-weeks intraperitoneal administration of $\mathrm{AlCl}_{3}$. Intraperitoneal (IP) administered $\mathrm{AlCl}_{3}$ of $0,7,35 \mathrm{mg} \mathrm{Al} / \mathrm{kg}$ body wt/day for 2 weeks in control, low Al (LA) and high $\mathrm{Al}(\mathrm{HA}) \mathrm{groups}$ respectively. Values in the figure with different ${ }^{A, B}$ superscripts are significantly different $(p<0.05)$.

thus, significantly higher in the high $\mathrm{Al}$ animals compared to the low $\mathrm{Al}$ and control animals.

\section{Anti-oxidative enzyme activities in different brain areas}

The SOD activities in the hippocampus were significantly lower in the HA $(0.51 \pm 0.02 \mathrm{unit} / \mathrm{mg}$ protein $)$ and the LA $(0.50 \pm 0.01$ unit/mg protein $)$ groups compared to the controls $(0.73 \pm 0.02 \mathrm{unit} / \mathrm{mg}$ protein (Figure $2 \mathrm{~A})$ ). So were the cerebellum $(0.27 \pm 0.06,0.33 \pm 0.02$, $0.45 \pm 0.04$ unit/mg protein; $p<0.05)$, and brain stem $(0.22 \pm 0.02, \quad 0.20 \pm 0.03, \quad 0.46 \pm 0.05$ unit $/ \mathrm{mg}$ protein; $p<0.05)$.

However, catalase activity in the diencephalon was significantly higher in the HA group than in the control group $(16.31 \pm 2.45$ unit $/ \mathrm{mg}$ protein v.s. $12.86 \pm 1.67$ unit/mg protein; $p<0.05$ ) (Figure $2 \mathrm{~B}$ ). Conversely, the catalase activity in the brain stem was significantly lower in the HA group than in the LA and control groups
$(15.78 \pm 3.88,25.90 \pm 1.38,23.52 \pm 1.93 \mathrm{unit} / \mathrm{mg}$ protein; $p<0.05)$.

The GPx activities in the hippocampus $(44.85 \pm 0.79$, $21.54 \pm 1.02,18.98 \pm 3.15$ unit $/ \mathrm{mg}$ protein; $p<0.05)$, cerebellum (31.53 $\pm 5.79,23.15 \pm 5.29,24.72 \pm 3.16$ unit/ $\mathrm{mg}$ protein; $p<0.05)$, and brain stem $(38.29 \pm 1.98$, $15.91 \pm 2.62,13.81 \pm 2.69$ unit $/ \mathrm{mg}$ protein; $p<0.05)$ were significantly higher in the HA group than in the LA and control groups (Figure 2C).

The correlations among aluminum, oxidative products, and anti-oxidative enzyme activities

The result of correlation analysis indicated that there was a positive correlation between aluminum contents and TBARS in the hippocampus, cerebellum, and brain stem $(\mathrm{r}=0.34, p=0.08 ; \mathrm{r}=0.69, p<0.05 ; \mathrm{r}=0.45, p$ $<0.05)$. Meanwhile, there was a positive correlation between aluminum contents and GPx $(\mathrm{r}=0.56, p<0.05$; $\mathrm{r}=0.55, \quad p<0.05 ; \mathrm{r}=0.49, \quad p<0.05)$, but a negative 
correlation existed between aluminum levels and SOD $(\mathrm{r}=-0.53, p<0.05 ; \mathrm{r}=-0.57, p<0.05 ; \mathrm{r}=-0.18, p=0.37)$ in the hippocampus, cerebellum, and brain stem. On the other hand, a positive correlation existed between aluminum contents and catalase in the diencephalon $(\mathrm{r}=0.56, p<0.05)$, while there was a negative correlation in the brain stem $(\mathrm{r}=-0.47, p<0.05)$.

\section{Discussion}

The initial objective of present study was to evaluate the accumulation of $\mathrm{Al}$ in the brains of neonates receiving high Al-containing commercial infant formula. However, it was not possible to conduct the analyses on human newborns. Three-week-old rats were, therefore, used to imitate 6-month-old infants during the breastfeeding period. Although previous studies have suggested that excess $\mathrm{Al}$ accumulates in the hippocampus, diencephalon, and cerebellum, no prior investigation has reported $\mathrm{Al}$ oxidative damage in various areas of the brain in neonatal rats. The present study's results suggest that toxic $\mathrm{Al}$ concentrations, and oxidative damage caused by $\mathrm{Al}$, occur in the 4 functional areas of the hippocampus, diencephalon, cerebellum, and brain stem in growing brain tissue.

\section{The pathological toxic concentration of Al in neonatal brain}

The results of present study showed that the $\mathrm{Al}$ concentration in the whole brain of neonatal rats (PND 17) were $165.5 \mathrm{ng} / \mathrm{g}, 167.4 \mathrm{ng} / \mathrm{g}$, and $219.5 \mathrm{ng} / \mathrm{g}$ which are much lower than the $\mathrm{Al}$ concentrations from our previous pilot work, $790 \mathrm{ng} / \mathrm{g}, 830 \mathrm{ng} / \mathrm{g}$, and $1440 \mathrm{ng} / \mathrm{g} \mathrm{re}-$ spectively when neonates were fed artificial rats milk at the dosage of $0,22.5$ and $225 \mathrm{mM} \mathrm{AlCl}_{3}$ respectively from PND 3 to 17). In addition, the levels of $\mathrm{Al}$ in the diencephalon, hippocampus, and cerebellum, were 1.5-8 fold higher respectively, in the gastrostomy bolus feeding groups (440.0 \pm 20.0 (HA) ng/g, $1180.0 \pm 30.0$ (HA), $1100.0 \pm 60.0(\mathrm{HA}) \mathrm{ng} / \mathrm{g})$ than that in the present work $(79.6 \pm 20.7$ (HA) ng/g, $751.0 \pm 225.8$ (HA), $144.8 \pm 36.2$ (HA) $\mathrm{ng} / \mathrm{g}$ ). It is suggested that $\mathrm{Al}$ levels in neonatal whole brain and/or various functional brain areas through the intraperitoneal injection would not exceed the physiological concentrations of $\mathrm{Al}$ from formula gastrostomy bolus feeding.

\section{The distribution of $\mathrm{Al}$ in neonatal rat brain}

When evaluating the effects of high $\mathrm{Al}$ on brain growth, the results indicated marginal changes in tissue weights in the cerebral cortex, pituitary, and olfactory bulb, as illustrated in Tables 1 and 2. However, no previous study has reported weight changes in these brain areas. Evaluations of $\mathrm{Al}$ distribution revealed that $\mathrm{Al}$ predominantly accumulated in the hippocampus, diencephalon (including the thalamus, metathalamus, hypothalamus, epithalamus, prethalamus or subthalamus, and pretectum), cerebellum, and brain stem (including the medulla oblongata, pons, and midbrain) of neonatal rats. Previous studies on adult rats have described $\mathrm{Al}$ accumulation in the same brain areas. Gomez and colleagues observed high levels of $\mathrm{Al}$ in the cortex, hippocampus, and cerebellum [24] of A $\beta$ PP transgenic mice provided $1 \mathrm{mg} \mathrm{Al} /$ $\mathrm{g}$ feed for 6 mo. Domingo and colleagues further described $\mathrm{Al}$ in the cortex, thalamus, and olfactory bulb in rats [25] following administration of $\mathrm{Al}$ at doses of 0 , 50 , and $100 \mathrm{mg} \mathrm{Al}$ ( $\mathrm{Al}$ nitrate) $/ \mathrm{kg}$ body wt/d in drinking water over $6.5 \mathrm{mo}$. Sanchez-Iglesias et al have also identified $\mathrm{Al}$ accumulation in the cortex, hippocampus, striatum, cerebellum, and ventral midbrain of rats following treatment with intraperitoneal injected or orally drinking with aluminum chloride [26]. The results of the present study indicated that administration of high concentration $\mathrm{AlCl}_{3}$ induced higher levels of $\mathrm{Al}$ accumulation in the brain stem. Consistent with previous studies on adult rats, distribution of $\mathrm{Al}$ mainly occurred in 3 specific areas in neonatal rat brain: the hippocampus, diencephalon, and cerebellum. Higher accumulation of $\mathrm{Al}$ also occurred in these brain regions in the neonatal rats. Results indicated limited deposition of $\mathrm{Al}$ in the cerebral cortex, pituitary, and olfactory bulb.

\section{Effects of Al on the production of oxidative products in the hippocampus, diencephalon, cerebellum, and brain stem}

The hippocampus, diencephalon, cerebellum, and brain stem tissues of high $\mathrm{Al}$ animals displayed significant increases in the levels of lipid peroxidative products (TBARS). Previous research, which involved oral administration of $\mathrm{Al}(0.1 \mathrm{mmol} / \mathrm{kg} / \mathrm{d})[27,28]$ or intraperitoneal injection of $\mathrm{Al}(7 \mathrm{mg} / \mathrm{kg} / \mathrm{d})$ for $11 \mathrm{wk}$ [29], also suggested that high accumulation of $\mathrm{Al}$ in the hippocampus increased the lipid peroxidative products. Similarly, Nehru and Bhalla reported elevated Al in the diencephalon of female Sprague Dawley rats administered with $\mathrm{AlCl}_{3}(40 \mathrm{mg} / \mathrm{kg} / \mathrm{d}$ ) for $8 \mathrm{wk}$, accompanied by increased lipid peroxidation in the hypothalamus (part of the diencephalon) [30]. Several other studies have shown that accumulation of $\mathrm{Al}$ in the cerebellum increased the lipid peroxidative products. In one study, oral administration of $\mathrm{Al}(100 \mathrm{mg} / \mathrm{kg} / \mathrm{d})$ for $2 \mathrm{mo}$ increased lipid peroxidation in the cerebellum of adult rats [31]. The cerebellar TBARS levels also increased in rats intraperitoneally injected with aluminum lactate $(7 \mathrm{mg} \mathrm{Al} / \mathrm{kg} / \mathrm{d})$ for $11 \mathrm{wk}$ [32]. Nehru et al further identified significant increases in lipid peroxidation in the cerebrum and cerebellum of pup brains following exposure of developed and developing rat brains to oral aluminum chloride $(100 \mathrm{mg} / \mathrm{kg} /$ d) for $6 \mathrm{wk}$ or $8 \mathrm{wk}$ [33]. Investigations on the brain 


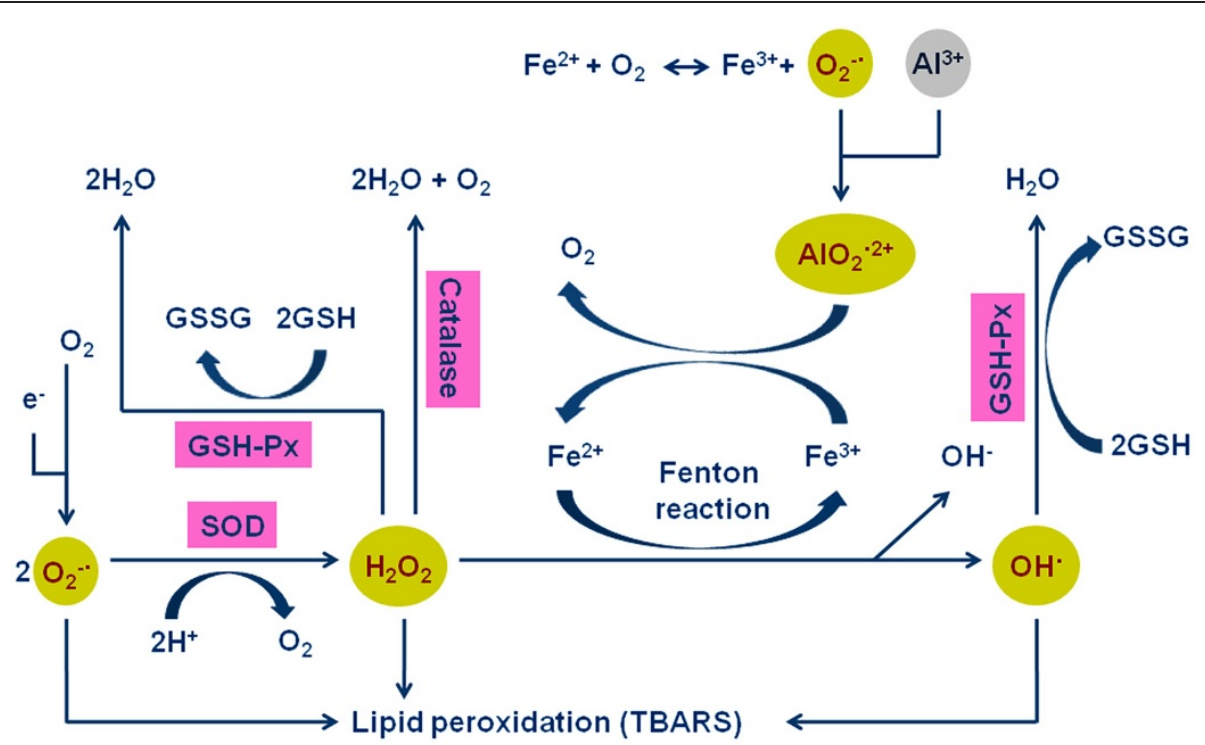

Figure 3 Diagrammatic representation of the relation among the aluminum (gray), reactive oxygen species (yellow), anti-oxidative enzymes (pink) and lipid peroxidation. TBARS = thiobarbituric acid reactive substances; SOD = superoxidase dismutase; $G P x=g l u t a t h i o n e$ peroxidase. (It is adapted from the research findings of Exley, 2004; Halliwell and Gutteridge, 2007).

stem have also demonstrated increased lipid peroxidation in the medulla oblongata $[30,34]$ and ventral midbrain [35] of adult rats. Results, therefore, suggest that increased lipid peroxidation in the brain stem was associated with high Al.

Two animal studies with high level of intraperitoneal injection of $\mathrm{Al}(7 \mathrm{mg} / \mathrm{kg} / \mathrm{d})$ for $11 \mathrm{wk}$ [29], and oral $\mathrm{Al}$ intakes $100 \mathrm{mg} / \mathrm{kg} / \mathrm{d}$ for $2 \mathrm{mo}$ [31], resulting in high $\mathrm{Al}$ contents, $22.26 \pm 12.7 \mu \mathrm{g} / \mathrm{g}$ in the hippocampus and $640 \pm 50 \mu \mathrm{g} / \mathrm{g}$ in the cerebellum respectively. Both showed the increase of oxidative products in the brain tissues. However, much lower $\mathrm{Al}$ concentrations in the hippocampus $(751.0 \pm 225.8 \mathrm{ng} / \mathrm{g})$ and the cerebellum $(144.8 \pm 36.2 \mathrm{ng} / \mathrm{g})$ could also induce the lipid peroxidation in the brain of the neonatal rat in our study. Therefore, it is quite possible to induce lipid per-oxidation of brain tissues in the neonatal animals even a slightly but significant increase of Al.

Effects of Al on the activities of anti-oxidative enzymes in the hippocampus, diencephalon, cerebellum, and brain stem

The present study's analyses comfirmed that high $\mathrm{Al}$ could induce oxidative stress and cause lipid peroxidation in the hippocampus, diencephalon, cerebellum, and brain stem. In these tissues, the initiation of antioxidative enzymes to oppose the oxidative stress was expected. Study findings revealed that the activities of SOD decreased with increasing lipid peroxidation in the hippocampus, cerebellum, and brain stem tissues of high $\mathrm{Al}$ animals. This was consistent with several other studies which identified significantly decreased SOD activities in the hippocampal region [28,35], cerebellum [33$35]$, and brain stem [34,35] in high $\mathrm{Al}$ animals. However, none of these four studies have measured the final $\mathrm{Al}$ concentration of brain tissues, although all had Al-overload through various routes, i.e. drinking water, intra-peritoneal, or oral gavage.

In our present study, the HA group displayed increased catalase activity in the diencephalon. The study of Nehru and Bhalla, however, described decreased catalase activity in the hypothalamus (part of the diencephalon) of high Al-treated rats [30]. The discrepancy of catalase activities between our study and this study might be due to the Al levels in the diencephalon. Unfortunately, no data of $\mathrm{Al}$ content was reported in Nehru and Bhalla' report. Nevertheless, it is believed that the regulation of catalase gene transcription is responded to modification of cellular redox levels. Spiegelman's study had reviewed that the role of PGC1 transcription coactivators are induced when cells are given ROS. PGC1 includes genes encoding proteins like SOD, catalase, and GPx [36]. Activated OxyR transcription factor switches on several genes encoding antioxidant functions, such as catalase, reported in Dample's study [37].

In the present study, GPx activity was significantly higher in the cerebellum, hippocampus, and brain stem in the HA group than in the other two groups. Similar results were reported by Esparza et al [32]. On the other hand, opposing results were shown in the hippocampus and brain stem following $\mathrm{Al}$ treatment $[28,35]$. Again, these studies also displayed with no data of the final $\mathrm{Al}$ 
concentration in brain tissue, even with $\mathrm{Al}$-overload by drinking water or intraperitoneally injection.

\section{Aluminum causes oxidative stress in neonatal brain through production of ROS free radicals}

The present study identified that $\mathrm{Al}$ induced production of the ROS free radical $\mathrm{H}_{2} \mathrm{O}_{2}$, which participated in oxidative stress in neonatal brain. Figure 3 proposed a theoretical diagram of the relationship between aluminum, ROS, anti-oxidative enzymes, and lipid peroxidation. It is adapted from the research findings of Exley, Halliwell, and Gutteridge [4,38], which suggested $\mathrm{Al}$ involved in the iron Fenton reaction in the brain. In this reaction, $\mathrm{Al}^{3+}$ (gray), $\mathrm{Fe}^{2+}$, and unpaired electrons mediate the production of ROS such as $\mathrm{O}_{2}^{-}$, $\mathrm{H}_{2} \mathrm{O}_{2}, \mathrm{OH}^{-}, \mathrm{OH}^{-}$, and $\mathrm{AlO}_{2}^{-}$(yellow). Superoxide dismutase activity indicated the production of $\mathrm{O}_{2}^{-}$, catalase and GPx activities confirmed the production of $\mathrm{H}_{2} \mathrm{O}_{2}$ and $\mathrm{OH}$ (anti-oxidative enzymes; pink). Negatively charged phospholipids of brain cell membranes, which contain polyunsaturated fatty acids, are easily attacked by ROS $[4,39,40]$. The present study used TBARS to represent peroxidative damage to phospholipids on cell membranes caused by Al. Results of significantly modified oxidative enzymes by $\mathrm{Al}$ deposition in neonatal brain tissues confirmed high $\mathrm{H}_{2} \mathrm{O}_{2}$ production in high $\mathrm{Al}$ brain. The increased $\mathrm{H}_{2} \mathrm{O}_{2}$ might induce peroxidization in a higher proportion of phospholipids to increase TBARS values. In the present work, the correlation analyses also confirmed the theory. This suggested that oxidative stress caused by high Al content is greater than the protection provided by the anti-oxidizing system; subsequently leading to high possibility of oxidative damage to brain tissue. Esparza et al reported that $\mathrm{Al}$ concentration in the brain tissue increased with increasing $\mathrm{Al}$ intake, but not in a dosedependent manner. Oxidative damage occurred in specific brain areas of adult rats [32].

\section{Conclusions}

The results of the present study demonstrate that excess $\mathrm{Al}$ accumulates in specific areas of the brain, including the hippocampus, diencephalon, cerebellum, and brain stem in neonatal rats following intraperitoneal injection of high levels of $\mathrm{Al}$. High $\mathrm{Al}$ significantly decreased the activities of SOD, but increased the activities of GPx and TBARS level in these specific brain regions. High $\mathrm{Al}$ accumulation might induce $\mathrm{H}_{2} \mathrm{O}_{2}$ production. The intraperitoneal administration of $35 \mathrm{mg} \mathrm{Al} / \mathrm{kg}$ body wt/d, therefore, increased oxidative stress in four specific brain areas in neonatal rats. These findings suggest a possible molecular mechanism for Al-induced oxidative damage in hippocampal and other brain cells. Further investigation of this mechanism, including behavioral analyses, is warranted.

\section{Abbreviations \\ Al: aluminum; LA: low Al group; HA: high Al group; ROS: reactive oxygen species; TBARS: thiobarbituric acid reactive substances; SOD: superoxidase dismutase; GPx: glutathione peroxidase.}

\section{Competing interests}

The authors declare that they have no competing interests.

\section{Acknowledgments}

Funding was received from the National Science Council, Taiwan. (NSC 942320-B-030-010).

\section{Author details}

'Graduate Institute of Nutrition and Food Sciences, Fu-Jen Catholic University, Hsinchuang, New Taipei City, Taiwan. ${ }^{2}$ School of Medicine, Fu-Jen Catholic University, 510 Chung-Cheng Road, Hsinchuang, New Taipei City 24205, Taiwan. ${ }^{3}$ Department of Nutritional Science, Fu-Jen Catholic University, 510 Chung-Cheng Road, Hsinchuang, New Taipei City 24205, Taiwan.

\section{Authors' contributions}

CYY designed the experimental protocol, performed the experiments and drafted the manuscript. GSWH contributed to the study concept, research design, data interpretation and manuscript revision. YJL contributed to the study concept, research design, data interpretation and manuscript revision. All authors read and approved the final version of the manuscript.

Received: 11 March 2012 Accepted: 21 May 2012

Published: 21 May 2012

\section{References}

1. Love $\mathrm{S}$, Jenner P: Oxidative stress in neurological disease. Brain Pathol 1999, 9:55-56

2. Youdim MB: Iron in the brain: implications for Parkinson's and Alzheimer's diseases. Mt Sinai J Med 1988, 55(1):97-101.

3. Verstraeten SV, Nogueira LV, Schreier S, Oteiza PI: Effect of trivalent metal ions on phase separation and membrane lipid packing: role in lipid peroxidation. Arch Biochem Biophys 1997, 338(1):121-127.

4. Exley C: The pro-oxidant activity of aluminum. Free Radic Biol Med 2004, 36(3):380-387

5. Chevion M, Berenshtein E, Stadtman ER: Human studies related to protein oxidation: protein carbonyl content as a marker of damage. Free Radic Res 2000, 33:599-108.

6. Kowalczyk E, Kopff A, Kędziora J, Błaszczyk J, Kopff M, Niedworok J, Fijałkowski P: Effect of long-term aluminium chloride intoxication on selected biochemical parameters and oxidative-antioxidative balance in experimental animals. Polish Journal of Environmental Studies 2004, 13(1):41-43.

7. Christen Y: Oxidative stress and Alzheimer disease. Am J Clin Nutr 2000, 71(2):621S-629S

8. Julka D, Gill KD: Effect of aluminum on regional brain antioxidant defense status in Wistar rats. Res Exper Med 1996, 196:187-194.

9. AA Abd el-Fattah, al-Yousef HM, al-Bekairi AM, al-Sawaf HA: Vitamin E protects the brain against oxidative injury stimulated by excessive aluminum intake. Biochem Mol Biol Int 1998, 46(6):1175-1180.

10. Katyal R, Desigan B, Sodhi CP, Ojha S: Oral aluminum administration and oxidative injury. Biol Trace Elem Res 1997, 57(2):125-130.

11. Toda S, Yase Y: Effect of aluminum on iron-induced lipid peroxidation and protein oxidative modification of mouse brain homogenate. Biol Trace Elem Res 1998, 61(2):207-217.

12. Yuan CY, Hsu GSW, Lee YJ: Aluminum alters NMDA receptor $1 \mathrm{~A}$ and $2 \mathrm{~A} / \mathrm{B}$ expression on neonatal hippocampal neurons in rats. $J$ Biomed Sci 2011, 18:81.

13. Snell RS: Clinical neuroanatomy for medical students (Periodicals). 5th edition. Philadelphia: Lippincott Williams \& Wilkins; 2001.

14. Blackburn ST, Loper DL: Maternal, Fetal, and Neonatal Physiology, A Clinical Perspective. Philadelphia: W. B. Saunders Company; 1992. 
15. Golub MS, Han B, Keen CL: Aluminum uptake and effects on transferrin mediated iron uptake in primary cultures of rat neurons, astrocytes and oligodendrocytes. Neurotoxicology 1999, 20(6):961-970.

16. Abu-Taweel GM, Ajarem JS, Ahmad M: Neurobehavioral toxic effects of perinatal oral exposure to aluminum on the developmental motor reflexes, learning, memory and brain neurotransmitters of mice offspring. Pharmacol Biochem Behav 2011, 101(1):49-56.

17. Gonda Z, Lehotzky K, Miklosi A: Neurotoxicity induced by prenatal aluminum exposure in rats. Neurotoxicology 1996, 17(2):459-470.

18. Guo CH, Liao SY, Yuan CH, Hsu WGS: Effects of peritoneal aluminum overload on polyamines and nitric oxide contents of testes and epididymis in the mice. Environ Toxicol Pharmacol 2006, 21:1-7.

19. Fraga CG, Leibovitz BE, Tappel AL: Lipid peroxidation measured as thiobarbituric acid-reactive substances in tissue slices: characterization and comparison with homogenates and microsomes. Free Radic Biol Med 1988, 4:155-161

20. Malstrom B, Andreasson L, Reinhammer B: In The Enzymes. XIIB. Edited by Boyer P. New York: Academic Press; 1975:533.

21. Johansson LH, Borg LAH: A spectrophotometric method for determination of catalase activity in small tissue samples. Anal Biochem 1988, 174:331-336

22. Paglia DE, Valentine WN: Studies on the quantitative and qualitative characterization of erythrocyte glutathione peroxidase. J Lab Clin Med 1967, 70:158-169.

23. Bradford M: A Rapid and Sensitive Method for the Quantitation of Microgram Quantities of Protein Utilizing the Principle of Protein-Dye Binding. Anal Biochem 1976, 72:248-254.

24. Gomez M, Esparza JL, Cabre M, Garcia T, Domingo JL: Aluminum exposure through the diet: metal levels in AbetaPP transgenic mice, a model for Alzheimer's disease. Toxicology 2008, 249(2-3):214-219.

25. Domingo JL, Llorens J, Sanchez DJ, Gomez M, Llobet JM, Corbella J: Agerelated effects of aluminum ingestion on brain aluminum accumulation and behavior in rats. Life Sci 1996, 58(17):1387-1395.

26. Sanchez-Iglesias S, Soto-Otero R, Iglesias-Gonzalez J, Barciela-Alonso MC, Bermejo-Barrera P, Mendez-Alvarez E: Analysis of brain regional distribution of aluminium in rats via oral and intraperitoneal administration. J Trace Elem Med Biol 2007, 21(Suppl 1):31-34.

27. Kaizer RR, Correa MC, Spanevello RM, Morsch VM, Mazzanti CM, Goncalves JF, Schetinger MR: Acetylcholinesterase activation and enhanced lipid peroxidation after long-term exposure to low levels of aluminum on different mouse brain regions. J Inorg Biochem 2005, 99(9):1865-1870.

28. Sharma D, Sethi $P$, Hussain E, Singh R: Curcumin counteracts the aluminium-induced ageing-related alterations in oxidative stress, $\mathrm{Na}+$, $\mathrm{K}+\mathrm{ATPase}$ and protein kinase $\mathrm{C}$ in adult and old rat brain regions. Biogerontology 2009, 10(4):489-502.

29. Gomez M, Esparza JL, Nogues MR, Giralt M, Cabre M, Domingo JL: Prooxidant activity of aluminum in the rat hippocampus: gene expression of antioxidant enzymes after melatonin administration. Free Radic Biol Med 2005, 38(1):104-111.

30. Nehru B, Bhalla P: Aluminium-induced imbalance in oxidant and antioxidant determinants in brain regions of female rats: protection by centrophenoxine. Toxicol Mech Methods 2006, 16(1):21-25.

31. Bhalla P, Dhawan DK: Protective role of lithium in ameliorating the aluminium-induced oxidative stress and histological changes in rat brain. Cell Mol Neurobiol 2009, 29(4):513-521.

32. Esparza JL, Gomez M, Rosa Nogues M, Paternain JL, Mallol J, Domingo JL: Melatonin reduces oxidative stress and increases gene expression in the cerebral cortex and cerebellum of aluminum-exposed rats. J Pineal Res 2005, 39(2):129-136.

33. Nehru B, Anand P: Oxidative damage following chronic aluminium exposure in adult and pup rat brains. $J$ Trace Elem Med Biol 2005, 19(2-3):203-208

34. Kaur T, Bijarnia RK, Nehru B: Effect of concurrent chronic exposure of fluoride and aluminum on rat brain. Drug Chem Toxicol 2009, 32(3):215-221

35. Sánchez-lglesias S, Méndez-Alvarez E, Iglesias-González J, Muñoz-Patiño A Sánchez-Sellero I, Labandeira-García JL, Soto-Otero R: Brain oxidative stress and selective behaviour of aluminium in specific areas of rat brain: potential effects in a 6-OHDA-induced model of Parkinson's disease. Neurochem 2009, 109(3):879-888.
36. Spiegelman BM: Transcriptional control of mitochondrial energy metabolism through the PGC1 coactivators. Novartis Found Symp 2007 287:60-63

37. Demple B: Radical ideas: genetic responses to oxidative stress. Clin Exp Pharmacol Physiol 1999, 26(1):64-68

38. Halliwell B: Gutteride JM: Free radicals in biology and medicine. 4th edition. New York: Oxford University Press; 2007.

39. Gutteridge JM, Quinlan GJ, Clark I, Halliwell B: Aluminium salts accelerate peroxidation of membrane lipids stimulated by iron salts. Biochim Biophys Acta 1985, 835(3):441-447.

40. Verstraeten SV, Golub MS, Keen CL, Oteiza PI: Myelin is a preferential target of aluminum-mediated oxidative damage. Arch Biochem Biophys 1997, 344(2):289-294.

doi:10.1186/1423-0127-19-51

Cite this article as: Yuan et al: Aluminum overload increases oxidative stress in four functional brain areas of neonatal rats. Journal of Biomedical Science 2012 19:51.

\section{Submit your next manuscript to BioMed Central and take full advantage of:}

- Convenient online submission

- Thorough peer review

- No space constraints or color figure charges

- Immediate publication on acceptance

- Inclusion in PubMed, CAS, Scopus and Google Scholar

- Research which is freely available for redistribution

Submit your manuscript at www.biomedcentral.com/submit
C Biomed Central 